\title{
Fishermen, Fishmongers, and the Sea Economic Restructuring and Gender Dynamics in a Philippine Community
}

This article provides a place- and work-specific exposition of gendered transformation in a local economy in Quezon province in the Philippines, where the declining productivity of fisheries since 1985 has seen a concomitant boom in fish marketing in nearby auction houses. It presents ethnographic data on seven families whose fishermen-husbands virtually abandoned fishing and assumed household management while their wives took on work as full-time fishmongers. The fishermen coped with the loss of economic clout by asserting masculine power, which resulted in spousal tensions, restrictions on their wives' mobility and social lives, and incidents of domestic violence.

KEYWORDS: FISHERMEN · FISHING COMMUNITY - GENDER - HOUSEHOLD • LOCAL ECONOMY • WOMEN FISHMONGERS 

fieldwork in San Juan in 2008, I was in a sari-sari store chatting with Raul, one of the fishermen there who had seen their fish landings greatly reduced over the years. Although he would still go fishing from time to time, the bulk of his family's income came from his wife, a fishmonger in the town market. When not out fishing, he would do household chores. He cooked their meals, looked after the children, and managed the daily affairs of the household. His wife, however, would spend the whole day selling fish. That day at the sari-sari store we were discussing local politics (the incumbent mayor was facing a possible recall election); so engrossed were we that we forgot the passing of time. Just as it was beginning to get dark, his wife popped into the store. With hands across her chest, she glowered at Raul, who was taken aback. "Napaigi, nakalimutan kong magsaing!" (“That's it, I forgot to cook rice!"), he said, sounding both frightened and apologetic. It was already dinnertime and he had not yet prepared anything for the family. He scampered away, his wife following after him. Days later the community was abuzz with gossip. Raul had beaten his wife, I was told. She was seen limping. Some said that she slipped on the floor while waxing it, fracturing her right foot, but others claimed that she was badly manhandled by her husband in the heat of an argument. I was aghast. At home, questions were playing in my mind. Was it because of what happened that night? Did Raul flex his masculine power because he felt humiliated by his wife's actions?

This article aims to explain the impact of transformations in the local economy - in this case, a localized fisheries crisis and a boom in fish marketing - on the gendered lives of a select number of people. The community in this study, here given the pseudonym San Juan, is a smallscale fishing community. Small-scale fishing is typically coastal and differs markedly in structure and function from large-scale fisheries pursued offshore (Vincent et al. 2007, 207). Highly diverse and dynamic, small-scale fishing is multimethod and multispecies (Bene et al. 2007, cited in Kleiber et al. 2014, 2), and fishers "fish close to their home communities in relatively near-shore waters in single day/night operations" (Kurien 1998, 3). In the Philippines small-scale fishing by law is restricted to municipal waters with a radius that extends to 15 kilometers from the shore and where big fishing boats are barred.
This article is part of a bigger study on San Juan, one of the many fishing communities that dot the long coastline of Lamon Bay, which forms the southern border of Quezon province facing the Pacific Ocean. Initial fieldwork was conducted in 2008-2009; subsequent visits were made between 2010 and 2014. This study looks into San Juan's economic, gender, and power relations as the community wrestles with the everyday challenges of a localized fisheries crisis (Turgo 2010). Participant observation and ethnographic interviews were the main qualitative methods used in data gathering. I participated in the daily life of San Juan, spending time at sarisari stores to listen to and participate in conversations, attending birthday and baptismal parties, and doing errands for some people such as looking after sari-sari stores and fish stalls on behalf of their owners.

By 2008 when I made my first ethnographic foray in San Juan, the small-scale fisheries there were already in rapid decline. The situation has remained the same, if not worsened. To small-scale fishermen in many fishing communities all over the Philippines, making a living is a struggle because of overfishing, illegal fishing, and unlawful competition from commercial fishing boats in municipal waters (Eder 2003; Fabinyi 2007; Guieb 2009; Mangahas 2000; Padilla et al. 2003).

\section{The Fishing Industry and Changes in the Local Economy}

The fishing industry's contribution to the gross domestic product (GDP) of the Philippines is placed at 1.9 percent and 2.2 percent at 2011 and constant 2000 prices, respectively. This contribution translated to some P183.1 billion at 2011 prices and P130.77 billion at constant prices of the country's GDP of P9,735.5 billion (at current prices) and P5,924.4 billion (at constant prices) (BFAR 2011). The industry employed a total of 1,614,368 fishing operators nationwide (NSO 2012), of which the municipal fisheries sector accounted for more than one million $(1,371,676)$ operators while the commercial and aquaculture sectors added some 16,497 and 226,195 operators, respectively (BFAR 2011).

The Philippine marine environment, especially its municipal waters, has been under siege. The country's coral reefs and the marine life they support have been severely impacted by the deadly combination of coastal population pressures, increased shoreline development, overfishing, and the rampant use of destructive fishing techniques such as cyanide and dynamite fishing (D’ Agnes et al. 2005, 2; cf. Fabinyi 2012; Philippine Senate 2013). 


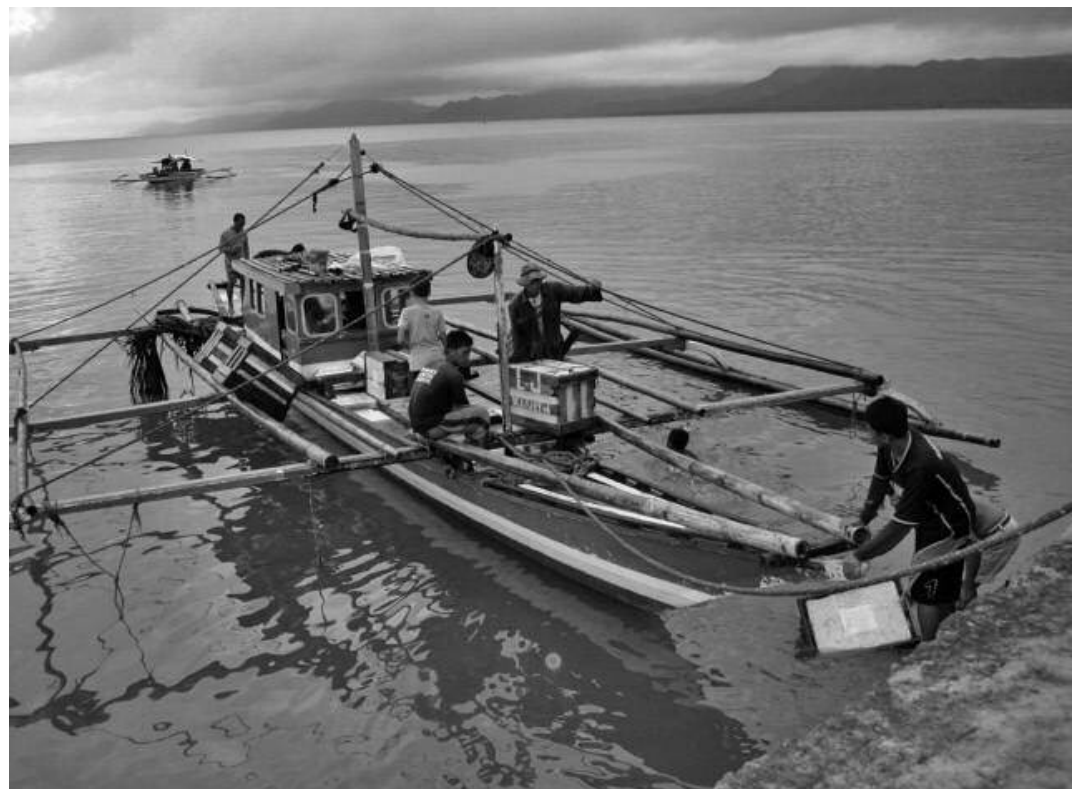

Fig. 1. Fishermen and day laborers of a fish auction house bringing fish landings ashore

The economic impact of these developments is worrying. For example, a briefing on the national economy by the Philippine Senate (2013) states that Philippine fisheries production has shrunk over the years due to overfishing, pollution, and climate change. Municipal fisheries production, in particular, went down by 3.88 percent in 2012 (ibid., 2).

The decline in catch, which has affected consistently the fishing grounds in Lamon Bay, has been felt most keenly by small-scale fishermen. Although it ranked as the fifth richest commercial fishing ground in the Philippines in 1995, with a total production of 55,252 metric tons, comprising 6 percent of the total national harvest, Lamon Bay has seen a declining fish catch since 1985 at the rate of 13.5 percent per annum, which is more than twice the national average of 5.4 percent (Campos et al. 2003; Turgo 2010, 4). Even if there was a boom in fish marketing in town, it did not mean that commercial fisheries was immune from the deteriorating state of most fishing grounds in the Philippines. In fact, during my last visit in 2014, the owners of fish auction houses were complaining that fish landings of commercial fishing vessels were also not as good as before, but they were holding on unlike small-scale fisheries (fig. 1). So far no current study has indicated that things

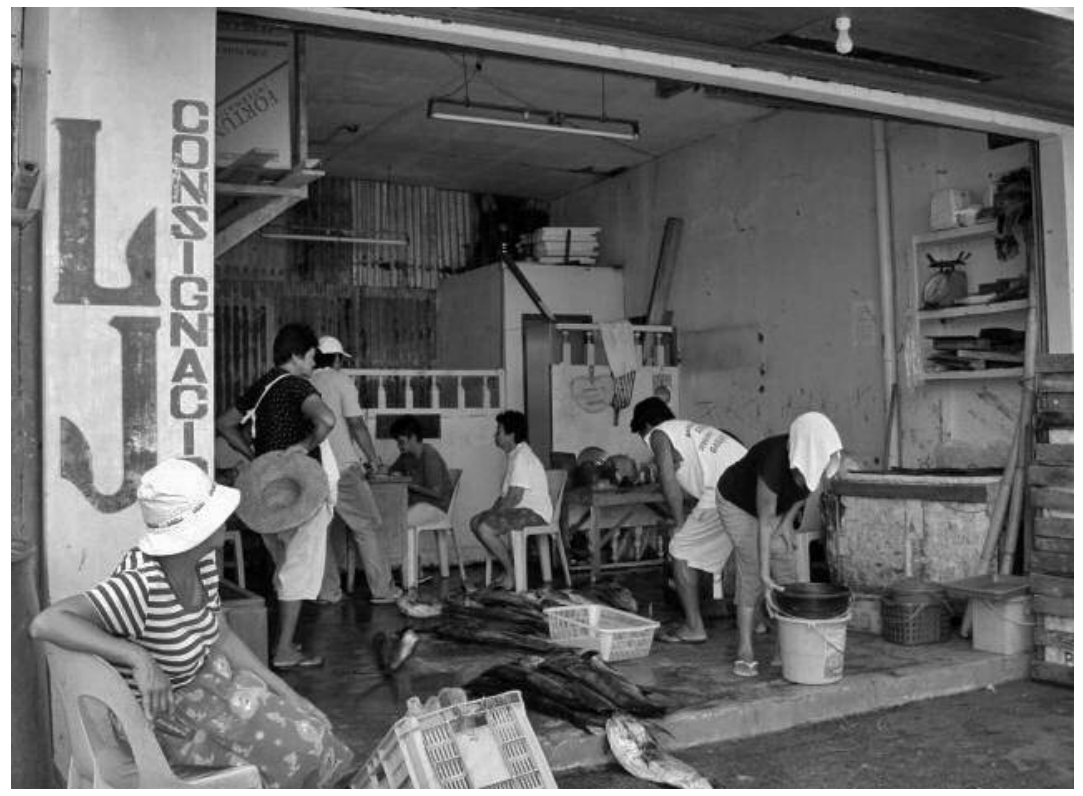

Fig. 2. A typical scene in a fish auction house

have improved for small-scale fishermen. If the experience of San Juan is anything to go by, fish landings have continued to decline.

Changes in the geography of the local economy became marked in the late 1990s when fishermen in San Juan noticed their reduced landings compared to those of previous years. While no existing statistics are at hand to quantify this decline, ${ }^{2}$ people commented on the absence of large landings of two local types of mackerel called galunggong (hard-tail mackerel) and alumahan (long-jawed mackerel) during the months of July and August. The acute dissipation of Lamon Bay's productivity has been attributed to many factors, most salient of which are the continuing proliferation of illegal fishing in the area, the incursion of commercial fishing in the fishing zones designated for small-scale fishermen, and the rapid peopling of coastal communities that put tremendous pressure on the bay's marine resources.

Interestingly, however, while small-scale fishing in San Juan has become untenable and unprofitable, fish marketing has boomed in the town where this village belongs. The brisk business in the town's four fish auction houses attests to this boom, spurred by developments in the large fishery sector in the area (fig. 2). Better fishing technologies have enabled some big commercial 
fishing vessels to exploit far-flung, hard-to-reach fishing grounds beyond Lamon Bay. This development has greatly improved fish landings in the town. In essence, while small-scale fishing has suffered, fish landings have improved courtesy of big commercial fishing vessels from other towns.

The boom in fish marketing was externally driven, because the commercial fishing vessels involved were from the neighboring towns. Owners of these fishing vessels would only employ fishermen from their own localities. In the town where I conducted this study, only one company owned big commercial fishing vessels, which had crewmen who were sourced mostly from fishing communities other than San Juan. Although a number of fishermen from San Juan used to work for this fishing company in the 1980s, by the time I conducted fieldwork no one worked for it. One reason the fishermen left, I was told, was the paltry income they received from the company relative to the huge amount of work they had to render. In recent years the fishing company had also reduced the number of its fishing vessels from five to two as it tried to channel its resources to other businesses like chicken farming and construction work in other places. Thus, for the past few years it had been reducing its workforce; whenever a vacancy arose, it would recruit only from among the families that had worked on their boats previously. Hence fishermen from San Juan could not find work in the commercial fishing vessels and in the only commercial fishing company in town.

However, fish marketing, which can be more lucrative than fishing, has opened other economic opportunities for many people in San Juan. Many women who pursued fishmongering as their main livelihood had been selling fish prior to the fisheries crisis, but the catch they sold were those of their husbands or next of kin. With their husbands' loss of income, these women turned to fish auction houses for the supply of fish to sell, in the process becoming their families' breadwinners.

\section{Fisheries and Gender Dynamics}

Participants in small-scale fisheries grapple with major ecological, social, economic, and governance challenges (Perry and Ommer 2003, cited in Neis et al. 2013, 13; cf. FAO 2013; Jones 2005; Kurien 1998; McGoodwin 1991; Sann 1998; Taylor et al. 2007). These transformations in and challenges to fishing communities have varying effects on how fishermen and their wives constitute their everyday lives, not least on household arrangements and other gender-related practices (Davis 2000; Davis and Gerrard 2000; Hapke 2001; Hapke and Ayyankeril 2004; Nadel-Klein 2000; Neis et al. 2013; Siason et al. 2000; Skaptadottir 2000, 2004; Weeratunge et al. 2010). The gendered dimension of transformations in the local economy revolves around what can be called the fishermen's experiencing of disrupted masculinity and the showcasing of hypermasculinity and their fishmonger-wives' staging of desirable femininity.

Disrupted masculinity refers to the inability of men to perform and express socially sanctioned and expected masculine behavior. When one's masculinity is disrupted, he is constrained from staging performances that define him as a man and radically differentiate him from being a woman. "Hypermasculinity involves the extreme valorisation of 'male' power (and consequent rejection of 'feminine' qualities and attributes) and the use of violence, if necessary, to maintain hegemony over others" (McMillan and Paul 2011, 368). As observed by Tony Evans and Patti Wallace (2008, 488), "hypermasculinity equals status, self-worth." When a man stages his hypermasculinity he is making a pronounced claim to power as a man and thus to his domination over others or those whom he does not regard as exhibiting man-like qualities, such as women, children, and homosexuals.

Desirable femininity refers to the valorization of qualities generally assumed by patriarchy to be the ideals for women like being motherly and tender, reserved and gentle, shy and obedient as opposed to being aggressive and confident or liberal and outspoken, qualities that are usually attributed to men. Desirable femininity highlights what women should be in the eyes of men, thus framing women under masculine gaze.

Studies in a number of places with declining fisheries or where transformations in the local economy were underway have shown that women face a greater burden than men (D'Agnes et al. 2005; Medard and Wilson 1996). The burden here is both physical and psychological because women have to double their efforts to make up for their husbands' greatly reduced income and at the same time attend to family problems and concerns. Studies in other places point to benefits and opportunities for women with the introduction of new fishing methods employed by commercial fishing vessels. For example, women fishmongers in Goa have more fish to sell and thus earn more while small-scale fishermen's income have stagnated or declined substantially due to their continued use of traditional fishing gear (Rubinoff 1999). Also illustrative are the outcomes of a moratorium on 
cod harvesting in Norway, with men reeling over the loss of their work and women seizing the opportunity to organize local celebrations and summer festivals to attract tourists and earn extra income (Gerrard 2000).

Men, however, are impacted differently depending on age, skills, and personal dispositions. For example, Medard and Wilson (1996) in their study of the economic problems faced by Nile perch fishing communities on Lake Victoria have shown that men suffer less than women from a decrease in economic opportunities. However, changes in the fishing economy affect men negatively in terms of their perception and experiencing of masculine power and authority (Davis and Gerrard 2000; Eder 2005, 2006). Failure in the abilities to work, earn, and support others (one's family), which are perceived as defining features of manhood (McMillan and Paul 2011, 367), results in low masculine self-esteem and self-worth.

In the Philippines studies on gender issues related to fishing and fishing communities focus mainly on the gender division of labor (De la Peña and Marte 2001; Siason 2001; Sotto et al. 2001), and gender-specific catch types and their impact on the marine environment (Siar 2003; Eder 2005; Guieb 2009). For example, Siason $(2001,71)$ contends that, while men do the hardwork of going out and doing the actual act of fishing, women do the postharvesting activities: "Fish processing and preservation is [sic] mainly the arena of women because it is associated with food preparation." Recent studies by Michael Fabinyi (2007) and Turgo (2014) provide a nuanced rendering of how notions of gender roles underline illegal fishing practice among young men in Palawan and how contestation over the meaning of masculinity pervades the choice between fishing and fishmongering among men in Quezon province.

These studies illustrate how men dominate the economic geography of fishing based on the ideology of economic complementarity, with women's work particularly in gleaning, fishing, and postharvesting activities recognized as complementary to men's (Kleiber et al. 2014). Nonetheless, there has been a research gap about the changing contours and experiencing of gendered lives by men and women in fishing communities in relation to economic restructuring. While studies by Fabinyi (2007) and Turgo (2014) advance the discussion of how masculinity gets redefined and contested in fishing communities, there is a need for further empirical elaboration of how people who depend on fishing enact and reenact their gendered lives amid transformations on all fronts. This gap is what this article seeks to fill by illuminating the many changing aspects of experiencing masculinity and femininity in one fishing community.

\section{Fishermen-Turned-Househusbands}

During my fieldwork 708 people lived in San Juan. Although it has long been known as a fishing community, in so many ways it is so only in name. For fifty-five families fishing and fishmongering were the main sources of income. Given an average of six members per family, it would mean that not more than 330 persons (or 47 percent) in the village relied on fishing and fishmongering for a living. Of these fifty-five families, seven relied solely on fishing and fishmongering while the rest did other kinds of work like, for men, carpentry and construction and, for women, doing laundry and selling cooked food. This article focuses on how these seven families experienced the gendered effects of the localized fisheries crisis in San Juan. The selected families were among those who felt most profoundly the radical changes in their experiencing and expression of masculinity and femininity.

These seven families had an average monthly income of P5,000 to P6,000 from March to September when fish auction houses were busy trading and fish was in relative abundance. From October to February their income would fall considerably as the bad weather that prevailed during this period constrained their ability to harvest and sell fish. The wives earned more than their husbands because fishmongering was done on a daily basis compared with fishing, which averaged one or two fishing trips per week only. While fishmongering could provide a steady income, earnings from fishing were highly variable; at times fishermen even incurred severe losses. The average age of men was 50, while for the women it was 48. But the youngest fisherman was 34 while the youngest fishmonger was 35 . The oldest fisherman was 65 while the oldest fishmonger was aged 62. Not counting the extended kin who lived with some of these couples, the average family size was six.

Unlike the rest of other fishermen who engaged incarpentry, construction, fishmongering (cf.Turgo2014), and other work outside fishing, the seven fishermen in these families had no other means of livelihood except occasional fishing. This situation rendered them vulnerable to a deep sense of insecurity and feelings of inadequacy - a case of disrupted masculinity - which resulted in the staging of hypermasculinity in order to redeem their sense of masculine self and power. In contrast the fishmongers, 


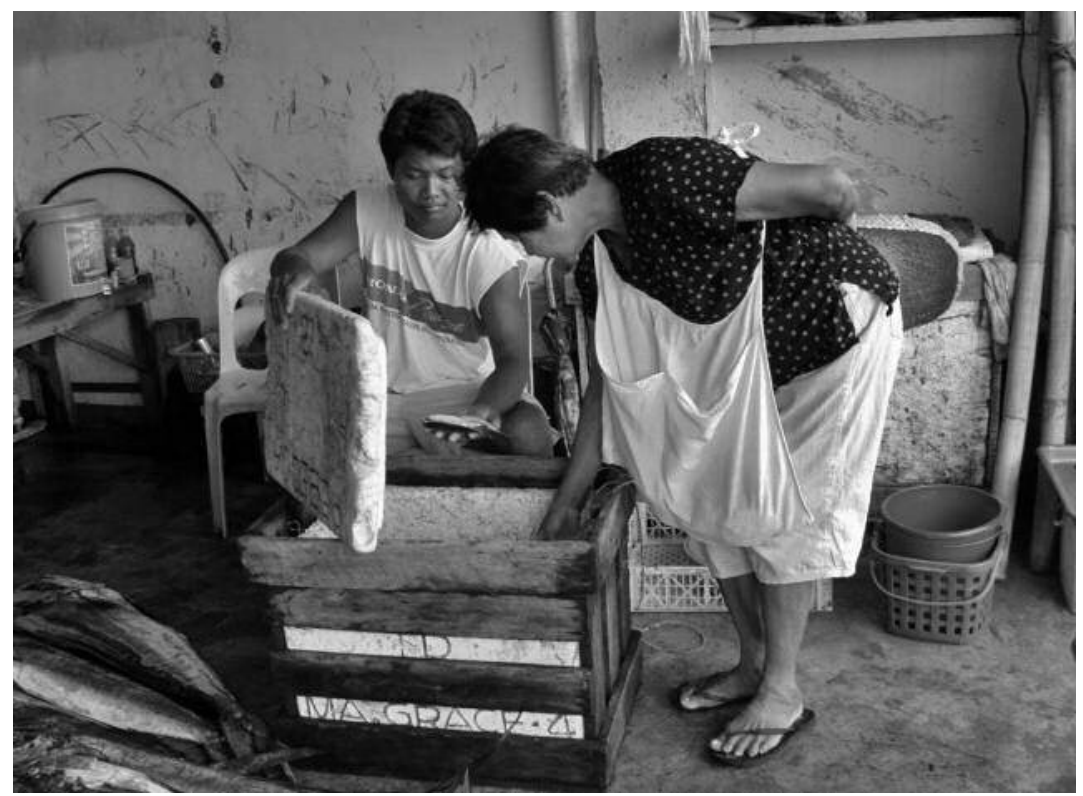

Fig. 3. Two fishmongers inspecting the quality of fish for auction in one of the fish auction houses

like most other local women, became the breadwinners; as such they usurped their husbands' main function as the family provider. Because the husbands in the seven families in this study did not venture into other types of work, the women's contribution to family income became even more salient. As the fishermen became "househusbands"(Pingol 2001) the wives experienced the most difficulties and adjustments to their husbands' sense of masculine disempowerment brought about by the fisheries crisis.

These fishermen's lack of alternative work was due either to their own choosing or to a number of circumstances beyond their control. For example, some fishermen refused to do fishmongering simply because they could not do a woman's job (Turgo 2014). A number of fishermen tried working in the city as construction workers but returned shortly after being unable to cope with the rigors and demands of construction work and city life. Others could not do carpentry work since they lacked the skills or were not as good as others and therefore could not compete. Lack of job opportunities in town also hindered them from seeking alternative work. Or, if there were opportunities, their local political affiliation or absence of social capital made their quest for work in many government projects simply untenable.
For these reasons they were forced to run the household while their wives earned money for the family (fig. 3).

My encounter with Raul and his wife,narrated at the beginning of the article, provided the impetus for this examination of gender dynamics amid the local fisheries crisis. My interactions and observations of daily life in San Juan helped me find the right informants. Initially I identified ten families, which I whittled down to seven as my data gathering progressed. For the women within the seven families I framed my two main questions:

Bago ang pagbagsak ng pangisdaan kung saan malaki pa ang kita ng inyong asawa, paano siya sa inyo bilang tatay at asawa? Magbigay kayo ng halimbawa.

Ngayong kayo na ang kumikita para sa inyong pamilya at ang inyong asawa ay umaasa na sa inyo, anu-ano ang mga pagbabago sa kanya? Kung may mga pagbabago, ano siya dati at ano na siya ngayon? Magbigay kayo ng halimbawa.

Before the decline in fish landings, when your husband was still making good money, how was he as a father and husband? Please give examples.

Now that you are the breadwinner in the family and your husband relies on your income, have you observed any changes to his character/demeanor? If there have been changes, can you compare how he was before and how he is now? Please give examples.

Following these questions, I explored the women's current experiences of their newfound role as family breadwinners and the challenges and difficulties that this role entailed. I interviewed the women when their husbands were not at home to ensure the honesty of their responses that otherwise might have been affected by their husbands' presence. When this arrangement was not feasible, as in the case of two of the seven women, I asked them to be interviewed in the house where I stayed during my fieldwork, some fifteen minutes from San Juan. Each interview lasted an average of an hour, but for three women the interview lasted three hours while the shortest interview lasted thirty-five minutes only.

With the men I conducted three formal interviews only. The other interviews were rather informal, and they happened in sari-sari stores and 
by the beach, mostly in the afternoon before sunset while the men were inspecting their boats. In addition, several conversations (locally known as kumbatihan) took place and focused on their experiences first as fishermen and then as household managers and on the difficulties and challenges brought by this change of role. With regard to their show of masculinity, two main questions were asked in the interviews:

Paano ninyo ikukumpara ang buhay ninyo noon bilang breadwinner at ngayon kung saan hindi na kayo kumikita ng ganoong kalaki?

Paano ninyo naipapakita sa inyong mga anak at asawa na kahit hindi na kayo ang kumikita para sa pamilya ay kayo pa rin ang padre de pamilya?

How would you compare your life then as breadwinner in the family and now when you are no longer earning enough?

How do you show to your children and wife that, even if you are not the breadwinner in the family anymore, you are still the "man of the house"?

The reluctance of some men in San Juan to be interviewed echoed the experiences of Hoang and Yeoh (2011) in their study of left-behind Vietnamese husbands whose refusal to talk openly about their experience betrayed their "inner conflicts or some deep frustrations that [they] . . consider too unmanly to disclose" (Pingol 2001, 17). In many instances, obtained stories involving verbal and physical abuse indirectly through the family's relatives and neighbors and from hearsay around the community. To ensure the veracity of these stories, I set the criterion of at least two people testifying that they were present when a particular event happened or they heard the story straight from the parties involved.

\section{Disrupted Masculinity: Fishermen under Siege}

Of the seven fishermen informants, those who engaged in intermittent fishing were the ones who expressed unabashedly a sense of great loss because of their inability to fish regularly and provide for the family. In so many ways, they lamented the loss of their masculine power-their failure to convert their mastery at sea to economic dominance. Because the sea was the source of their livelihood and, by extension, power, inadequate income from fishing was tantamount to loss of power in the household and their sense of being a man. This was so because of the perception across cultures that "to be a man implies that one has to be a breadwinner" (Brittan 1989, cited in Hoang and Yeoh 2011, 719; cf. Elmhirst 2007; Fuller 2001; Parreñas 2005; Walter et al. 2004). The sea was their domain, and they dominated the economic sphere of the community; the loss of one meant the loss of another. However, this sense of loss was not just economic but also symbolic.

Masculinity, as seen in the wider literature, is something achieved, a set of performative acts; "it is defined more through what it is not (female, gav, and so on) rather than what it is"(Evans and Wallace 2008, 486). In this sense, since "fishing and masculinity are culturally closely related" (Munk-Madsen $2000,339)$ and "sea is central to the local constructions of masculinity" (Davis 2000, 348; cf. Fabinyi 2007), their prolonged absence from fishing creates a void, a feeling of inadequacy, and, as one of them said, parang isdang nasa tahik ("like fish out of water"). Masculinities are assumed to falter at times when men are disempowered by socioeconomic changes that make it hard for them to assume their position as "providers" (Elmhirst 2007, 229). Not doing much fishing and being unable to be a provider translate to feeling less of a man, a sense of disrupted masculinity. Echoing the findings of Binkley $(2000,332)$ on the effects of the fisheries crisis in Nova Scotia on fishermen, this article argues that "the decline in wages, or the loss of work erodes fishers' self-esteem and aggravates their anxiety."

One example is Raul, who is mentioned at the beginning of this article. His irregular fishing made his family rely on the income of his wife as a full-time fishmonger. In the morning his wife would cook breakfast while he prepared their children for school. When the children had gone to school and his wife to fish auction houses, he would start to clean the house. When he was done with the household chores, he would go out and chat with friends. At around $11 \mathrm{am}$, he went back to the house to prepare lunch. After his afternoon nap he left the house at 3 pm to check on his boat (this chore had become a ritual of sorts for these men in the community) and then spend the rest of the afternoon conversing with friends. By 5 pm he would prepare dinner and by 7 pm dine with his wife, with their children usually eating dinner earlier than them. Sometimes his wife helped clean up the dishes, but a whole day's work often made her exhausted. He was then left to wash the dishes. Oftentimes, too, he would see to it that the children were working on their school assignments before he left the house to watch television in 
Ari ako ngay-un, laging nasa bahay at kaistoryahan ang mga kaibigan. Para na akong pensionado. Ako nama'y hindi ba kumportable sa ganito dahil ako nama'y hindi sanay na pirming nasa bahay, ay. Ako ngay-un ay "tatay kong nanay."

Here I am now, always staying at home and chatting with friends. I am like a pensionado [one living on a pension]. I'm not really comfortable with this because I'm not used to being always at home. Now I am a father who is also a mother. (Raul 2008)

Among themselves the men felt that the longer they stayed at home and away from the sea, the more they harbored a sense of being less of a man (parang hindi na totoong lalake). Quite used to a fast-paced life and the demands of physical work at sea, they found the everyday routine at home totally alienating and confusing. This situation finds resonance with some of the stories recounted by Asis and colleagues (2004) in their study of families whose women worked overseas and whose men stayed behind to run the household. For example, when I visited a fisherman in his house for an interview, I found him bathing his four-year-old daughter. Seeing the toddler crying I thought that his way of bathing her was a bit heavy-handed. He was struggling and lacked the tenderness often associated with women in handling kids. After the interview, I wrote down in my notebook:

He looked rather worse for wear and the house mirrored his poor physical countenance. The house looked like a war zone and clearly, Eric struggled very hard in his new role. Some dirty clothes were heaped on top of one another in a corner. The air in the house was odious, maybe because of the unwashed wet clothes. He felt embarrassed that I chanced upon their house in total disarray.

However, more than the chores at home, the men commonly lamented the displacement of their being the arbiter of power and authority in the household. According to Mayo (2008) he made decisions for the family when he was still earning enough for them. Although decisions were not unilateral

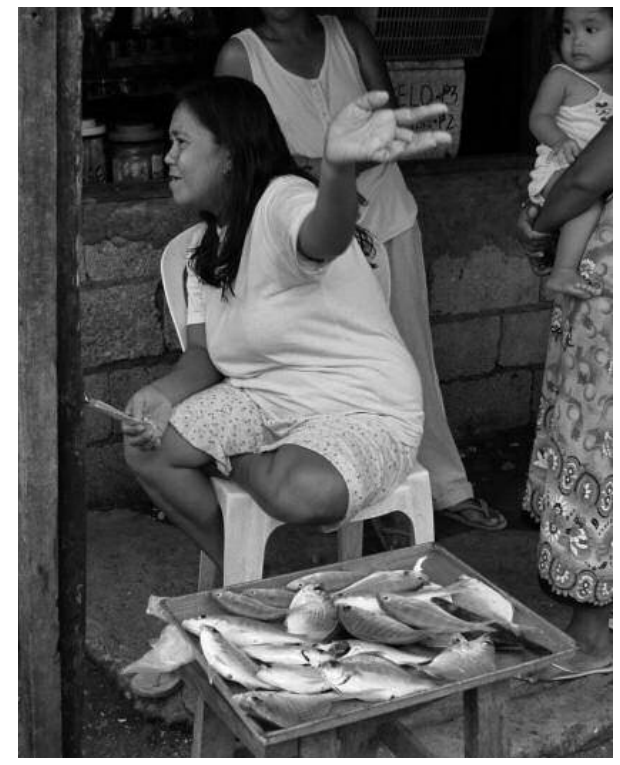

Fig. 4. A fisherman's wife selling fish on the street

but mostly between him and his wife, he always insisted on his option as the best whenever they disagreed. When his children wanted new shoes and he said no, his decision could not be overturned. However, things had changed since his wife started earning for the family and he was earning less and less. For example, he mentioned how his oldest son, who was in his final year in high school, wanted to join a school field trip. When his son asked for his permission, he wanted to say no because of the huge expense involved. When his wife asked for his opinion he said no, but she said there was enough money for it. He ended up leaving the decision to her.

Ay ano pa't tatanungin ako kung siya rin naman pala ang masusunod, hane? Ay, ito'y hindi ari kung ako pa rin ang kumikita. Ay pero dahil ang asawa ko'y mas malaki na ang hanap kaysa sa akin, ay siya na ang nagpapasya. Ako'y tagasunod na lamang kumbaga.

Why should she ask me, if anyway she would have her way, shouldn't she? This cannot be if I were still the one earning. But because my wife's earnings are bigger than mine, she is the one making the decision. I just obey her, as it were. (ibid.) 
There are other examples of the diminution of their authority and influence at home and even in community affairs. ${ }^{3}$ The men told me that their wives now openly argued with them over family issues, when previously they just kept mum; their wives pressed ahead with the purchase of some things without consulting them beforehand. At other times, when they asked money for alcohol, their wives either coldly said no or gave money nonetheless but not without admonishing them or going into a lengthy discussion about how money was difficult to earn.

However, regardless of this protestation of feeling emasculated by the turn of events in the local economy, men in San Juan had a way to reclaim and assert their authority and power over women. They could still stamp their commanding presence and masculinity in the household and in the community and claim their centrality in the household, albeit at times with the consent of their fishmonger-wives (fig. 4).

\section{Displaying Hypermasculinity}

The role reversal that occurred in some households in San Juan did not mean, however, that the men who had to rely on their wives for their everyday needs would give up their dominant status in the household and in the community without a fight. In the realm of the symbolic, men who had to do things that fell under the domain of women felt violated. The feeling of inadequacy was pervasive as shown by the sentiment of a number of fishermen cited above. Hypermasculinity - "a rigid gender role script" (Mosher and Sirkin 1984, cited in Guerrero 2009, 136) — was a way to counter this feeling. In order to reestablish their power and authority and in some way reclaim their lost ground and self-respect, the fishermen recalibrated how they acted out their gender practices.

One example is the incident narrated at the outset. A day after my conversation with Raul, the community was abuzz with the news that Raul had a quarrel with his wife that caused her physical harm. I was then pressed to find out whether the rift was triggered by Raul's exposure to public ridicule when his wife "confronted" him in the store. Some weeks later, when all was forgotten and the news was superseded by other more interesting news in the village, I had the chance to talk to Miriam, Raul's wife. Raul was then out at sea, on one of those infrequent days that he went fishing. ${ }^{4}$ She confirmed that she had a quarrel with Raul and that he manhandled her. Apparently Raul did not like being seen as someone who could be bossed around in public.
Ayaw na ayaw noon na siya'y aking pinagalitan sa harap ng marami. Napapahiya daw siya. Iyu'y nagagalit kapag siya'y pinagsasabihan na may kaharap na maraming tao.

He dislikes it very much that I scold him in front of many. It shames him, he says. He becomes angry when you tell him off in front of many people. (Miriam 2008)

Miriam confided that, although it was not the first time that she had a confrontation with her husband, it was her first time to be physically assaulted. Oftentimes they would have petty quarrels over her husband's failure to do his share of housework while she was away. As her husband slowly adjusted to his new role in the household, the frequency of their quarrels lessened. However, there were days when Miriam was on the edge, bone-tired, and sometimes troubled by some issues with the owners of the fish auction houses such that she could not help but feel angered and frustrated by her husband's failure to prepare dinner or keep the house tidy. The day when she saw us in the store was one of those days. She had been selling fish the whole day and managed to earn a measly P150.00, way below her usual daily intake of P250.00. She returned home disappointed, only to find the house in total disarray and the food not yet prepared. Out of sheer frustration she went to look for her husband and show him what she felt. Apparently, when she appeared in front of us, standing in silence, Raul took offense because he was made to appear stupid not just in front of their friends but in front of me.

Ang sabi sa akin ay pinahiya ko daw siya sa harap mo. Sabi ko nama'y yun ay bale wala sa iyo. Ay ayaw pa ring makinig. Siguro'y dahil sa inis ay bigla akong tinulak.

He told me that I embarrassed him in front of you. But I said that it means nothing to you. But, hey, he wouldn't want to listen. Maybe he got irritated that he suddenly pushed me. (Miriam 2008)

Miriam “confronting” Raul did not just embarrass him but also reminded him of his subordinate position in the household. It highlighted his disrupted masculinity. He felt symbolically assaulted. It further underscored his diminished stature in the household and in public. In resorting to physical 
force husbands reaffirm their sense of masculinity because, as Evans and Wallace $(2008,486)$ contend, "performing the type of masculinity that sits on top of the pile in terms of power frequently involves violence or threat." Other reported incidents of physical abuse of wives by their husbands in the community (although during my stay I witnessed one incident only) had taken place mostly when fishermen felt publicly humiliated by their wives.

Aside from physical abuse, fishmongers had also felt the curtailment of their movement and activities, even their demeanor in public, which they had a degree of latitude to exercise prior to the decline in fishing and the reduced economic activities of their husbands. As husbands relied more and more financially on the wives, the men felt more threatened and insecure and thus exaggerated their expression of dominance and masculinity. Sara, for example, told me that when her husband was still the breadwinner in the family he was always away at sea and had no way to monitor her activities. When he was at home, he never bothered to ask her about her activities for so long as the house was in order. But since her husband was spending more of his time at home and had more time to monitor her movements, he became more questioning.

Ay ngay-un kailangang sabihin ko sa kanya kapag ako'y male-late ng uwi. Ay alam na alam naman niya na hindi ko hawak ang oras ko. Minsan talaga'y matumal ang isda at matagal mabenta at dahil ako'y nadayu pa sa malayo, minsan ako talaga'y ginagab-i. Talagang nakakabareno kapag ang asawa mo ba'y sinasabihan ka na umuwi ka ng maaga.

Nowadays I have to tell him if I would come home late. But he knows very well that I don't control my time. Sometimes fish vending is really sluggish and it takes time to sell and because I have to go to distant places sometimes I really get home by nighttime. One really gets outraged when your husband tells you to come home early. (Sara2009)

In a way the fishermen's prolonged absence from the sea opened their eyes to the world of possibilities their wives enjoyed. They saw this world as a threat to their masculine power and authority. As a result, another fishmonger spoke of her reduced involvement in social activities in which she had indulged greatly before her husband had been relegated to managing the household. Nowadays she had become very conscious of her time. Her husband was always hot on her heels.

While some fishmongers did not experience this kind of curtailment in terms of their social activities, they nonetheless felt that in some ways their husbands had become more prescriptive of what they could say and do in public. For example, when Adela bought a new dress and showed it to her husband, he told her that he thought it to be too revealing and unfit for her age (she was 50). She thus gave the dress away to her younger sister. In another instance, when a fishmonger decided to have a haircut in a relatively expensive beauty salon in the city as a birthday gift to herself, her husband accused her of being extravagant and flirting around. There was a heated argument that almost ended in a physical altercation.

Observations with regard to Mexican men who failed to migrate to the US and were left at home (Boehm 2008, 21) resonate well with the lives of the fishermen in San Juan: "For men who do not migrate, masculinities are often expressed through exaggerated performances of manliness, arguably a kind of compensation for not fulfilling the expected role of migrating." In the face of their wives usurping their prime economic role in the household, the "left-behind" husbands of Vietnamese migrant workers have also sought to reassert their agency and authority, thus their masculine power and dominance, by highlighting the fact that without their consent their wives would not be able to work overseas (Hoang and Yeoh 2011).

\section{Performing Desirable Femininity}

Faced with all the radical changes in their husbands' behavior, the fishmongers were quick to highlight that their husbands used to be different: Their husbands were not physically violent with them and they did not assault their wives physically. In her case Miriam told me that Raul used to be very gentlemanly and had never lifted a finger at her. She attributed his outburst of violence to his frustration over his failure to provide for the family. As far as she was concerned, Raul would not have done what he did if only he were still earning enough for the family instead of relying on her for the family's everyday needs. Sara echoed this observation when she said that her husband used to not care where she went or the kind of dress she wore. Fishmongers observed that changes in their husbands' behavior happened only after the fishermen started to rely on them for the family's needs. 
Some fishermen asserted their masculine power in the household by other means with the cooperation of their wives. Regardless of their central economic role, these wives opted to reiterate their traditional role in the family. They downplayed their contribution and positioned themselves as "just doing their part." They chose to emphasize their role as supportive of and submissive to their husbands. They feigned and showed subservience to their husbands. They performed gender practices that highlighted desirable femininity in the eyes of their husbands.

Liza's case illustrates how fishmongers deployed feminine gender practices to reestablish their husbands' lost sense of power and authority. My interview with her was postponed several times because our schedules did not match. She said that having the interview was impossible because she did not know the time she would return home from a whole day of selling fish. She added that, once she got home, she would still be busy with household chores. After I had waited for some weeks, she informed me that she would be free one Saturday afternoon, so I went to her place and interviewed her. While we were discussing her family life, her husband came in from playing volleyball. He told Liza that he was hungry and asked if she could prepare something for him. Liza excused herself, took some food from the pantry, and laid the food on the table. She also prepared a mug of coffee. While her husband was eating we stopped talking, as Liza had to go upstairs to get a shirt. When her husband asked for a glass of water, Liza stood up again and served her husband. When he was done eating he stood up, left the table, and went out. Liza (2009) explained the behavior of her husband in this way:

Iya'y nagsimulang maging ganyan, mayayamutin no'ng hindi na masyadong makalaot. Ay pinapabayaan ko na lamang na gawin ang gusto niya, dyata'y. Ako nama'y ginagawa ko na din lamang ang gusto niya. Kung may gusto siya at alam ko namang kaya niya ay kumikilos na din ako para walang masabi. Ay nauunawaan ko din naman ang pinagdadaanan niya.... Pabayai na, lalaki'y ganyun talaga.

He started to be like that, irritable, when he could no longer venture into the deep sea. So I just let him do whatever he likes, shouldn't I? On my part I also just do whatever he likes. If he wants something, even if I know he can do it by himself, I just act on it so he won't have anything to complain about. Yet, I also understand what he's going through ... Let him be, men are really like that.

Shedding light on Liza's case, Munk-Madsen (2000) explains that women care much about the masculine identity of their husbands by undercommunicating their own economic successes and normalizing and sanitizing their husbands' hypermasculinity. Furthermore, women support the masculine identity of their husbands by not threatening the symbolic value of their authority.

The women's disavowal of their importance and their continued subservience to their husbands underscored the fraught and conflicted social field that women in the community negotiated. They kept a low profile and tried their very best to cater to their husbands' whims and caprices. In a way these women actively maintained a façade of "normalcy" and preserved the structure of hegemonic masculinity in their everyday lives. They employed such gestural practices, which highlighted instances of desirable femininity, also to negotiate their survival when their husbands displayed hypermasculinity. As one fishmonger told me, she wanted peace and quiet at home and thus refused to contest her husband's kabayagan (bravado). Hence, women were also conscious of their newfound role in the household and saw that the best way to deal with their new power was to downplay it and rechannel it to the powerless - their husbands.

\section{Conclusion}

This article does not purport to cover a whole array of issues affecting the life experiences of men and women in one fishing community in Quezon province; rather it has elected to focus on how a select group of fishermen and fishmongers' lives had been changed by the restructuring of the local economy, resulting in basic role reversals. The fishermen husbands became housekeepers while the wives as fishmongers became the principal income earners. In their case (but not among the men who found work outside fishing), the violence of the local economic restructuring showed in the experiencing and staging of different gender dynamics by both fishermen and their wives. Because of economic disempowerment due to the decline in fishing, the men experienced disrupted masculinity, resulting in the display of hypermasculinity and a diversity of responses among the wives ranging from asserting their 
newfound power (which could trigger physical abuse by the men) to the performance of desirable femininity.

Economic restructuring, it is normally argued, tends to reinforce and exacerbate existing gender inequalities, furthering the domination of men and the marginalization of women (Hapke and Ayyankeril 2004; Pyle and Ward 2003). This article provides additional empirical evidence and lends further credence to Easkey Britton's (2012, 17) observation that "gender roles within the household are in transition as a result of increasing male unemployment and increasing number of women entering the workforce. This can create greater responsibility for women and the erosion of self-worth for men, leading to tensions within the home where these roles are negotiated."

This article speaks to the wider literature dealing with the effects of economic restructuring on the lived experiences and gender roles of men and women, reinforcing the findings of a number of studies undertaken in other contexts (e.g., Elmhirst 2007; Fuller 2001; Kabeer 2007; Menjivar 2006; Silberschmidt 2001). The findings of this study suggest convergences of experiences that occur among men and women in different places who are faced with similar challenges brought about by the changing contours of today's local economies. Thus we need to pay heed to the many and yet oftentimes converging, but always conflictual and changing, worlds ushered in by these economic transformations for us to better understand how men and women, fishermen and fishmongers alike, make sense of their changing fortunes and react through varied gendered means.

In this article the analysis of the changes that some fishermen and their wives experienced did not consider the analytic significance of factors like kinship, social network, age, and educational qualifications. However, it may be noted, for example, that those who experienced physical abuse from their husbands had limited kinship ties since they hailed from other localities. In contrast, those who had extensive kinship ties in the community and lived close to their extended families seemed to have been spared the brunt of their husbands' show of hypermasculinity. These other factors might further our understanding of how people react to and cope with the changes around them. In addition, this article did not touch on the ways some fishmongers protested their lot through the enactment of everyday forms of resistance (Scott 1985) to their husbands' display of hypermasculinity when they flexed muscles and lorded over the community's economic field. Other researchers might want to pursue these leads in the future.
Concomitantly, the changes observed in this study could simply be a phase in the way fishermen and their fishmonger-wives make sense of their new roles in the household economy. As new opportunities emerge, gender dynamics may change again. That everything is in flux and therefore transitory has never been lost on many fishmongers, who expressed the hope that things would return to normal once the problems in the local fisheries are fixed or their husbands finally decide to let go of fishing and find work elsewhere. Some fishmongers also expressed their desire to stop working and return to running the household. That women are meant to look after the family while men do productive work is a notion still deeply ingrained among them. Fishermen who had become tired of their prolonged state of inactivity have also held this view. They want fishing in the area to be lucrative again so that they can go back to their boats and launch them to sea regularly.

As fishing communities in the Philippines face endless challenges and difficulties brought about by both internal and external forces, we can do no less than take stock of how bounded sites (Candea 2007), like the fishing community studied here, echo the murmurings of shifting gender boundaries in many other parts of the world.

\section{Notes}

1 Sari-sari stores are home-based small- to medium-sized stores, most popular in rural areas and low-income enclaves in urban settlements. They sell all kinds of goods, in small quantities and portions. For illuminating discussions on sari-sari stores, see Turgo 2013; Dannhaeuser 1980; Silverio 1982.

2 This town's Municipal Agriculturist Office (MAO), which is mandated by Philippine law to gather data about fisheries and fish landings in the area, had no relevant statistics. The authorities concerned cited lack of personnel to monitor daily fish landings and the lack of cooperation of fish auction house owners.

3 As an instance of these fishermen's peripheralization in community affairs, I once attended a barangay general assembly. As a barangay councilor acknowledged the presence of the attendees, a town folk commented that he had not seen a fisherman for quite sometime in these assemblies. His wife stood up and said, for everyone to hear, "Hindi 'yun puedeng maabala at nag-aalaga ng anak!" ("He can't be bothered because he is looking after our children!"). The assembly broke into a guffaw.

4 In this regard men often went fishing not to earn good money, which seldom happened, but, as the fishermen told me, to rekindle their relationship with the sea. Fishing was their hilig (predilection, liking, desire) (see, e.g., Eder 2006); fishing allowed them to unwind and renew themselves. 


\section{References}

Asis, Maruja Milagros, Shirlena Huang, and Brenda S. A. Yeoh. 2004. When the light of the home is abroad: Unskilled female migration and the Filipino family. Singapore Journal of Tropical Geography 25(2): 198-215.

Bene, C., G. Macfadyen, and E. H. Allison. 2007. Increasing the contribution of small-scale fisheries to poverty alleviation and food security. FAO Fisheries Technical Paper, 481. Rome: Food and Agriculture Organization

Binkley, Marian. 2000. "Getting by" in tough times: Coping with the fisheries crisis. Women's Studies International Forum 23(3): 323-32.

Boehm, Deborah A. 2008. "Now I am a man and a woman": Gendered moves and migrations in a transnational Mexican community. Latin American Perspectives 35(1): 16-30.

Brittan, Arthur. 1989. Masculinity and power. Cambridge: Basil Blackwell.

Britton, Easkey. 2012. Women as agents of wellbeing in Northern Ireland's fishing households. Maritime Studies 11(16): 1-22.

Bureau of Fisheries and Aquatic Resources (BFAR). 2011. Agriculture and fisheries statistics. Quezon City: Department of Agriculture, Republic of the Philippines.

Campos, Maribec A., Blanquita R. Pantoja, Nerlita M. Manalili, and Marideth R. Bravo. 2003. Economic evaluation of fishery policies in Lamon Bay, Quezon, Philippines. Ontario: International Development Research Centre. Online, http://www.idrc.ca/en/ev-61208-201-1-DO_TOPIC. html,accessed 17 Mar. 2014.

Candea, Matei. 2007. Arbitrary locations: In defense of the bounded field-site. Journal of the Royal Anthropological Institute 31(1): 167-84.

D'Agnes, Heather, Joan Castro, Leona D'Agnes, and Rhona Montebon. 2005. Gender issues within the population-environment nexus in Philippine coastal areas. Coastal Management 33:447-58.

Dannhaeuser, Norbert. 1980. The role of the neighborhood store in developing economies: The case of Dagupan City, Philippines. Journal of Developing Areas 14(2): 157-74.

Davis, Dona. 2000. Gendered cultures of conflict and discontent: Living 'the crisis' in a Newfoundland community. Women's Studies International Forum 23(3): 343-53.

Davis, Dona and Siri Gerrard. 2000. Introduction: Gender and resource crisis in the north Atlantic fisheries. Women's Studies International Forum 23(3): 279-86.

De la Peña, L. and C. L. Marte. 2001. The plight of older women in a fishing village: The women fish traders of Bugtong Bato, Aklan, central Philippines. In International symposium on women in Asian fisheries (Fifth Asian Fisheries Forum, 13 November 1998, Chiang Mai, Thailand), ed. M. J. Williams, M. C. Nandeesha, V. P. Corral, E. Tech, and P. S. Choo, 165-172. Penang: ICLARMWorld Fish Center.

Eder, James F. 2003. Of fishers and farmers: Ethnicity and resource use in coastal Palawan. Philippine Quarterly of Culture and Society 31:207-25.

2005. Coastal resource management and social differences in Philippine fishing communities Human Ecology 33(2): 147-69.

2006. Gender relations and household economic planning in the rural Philippines. Journal of Southeast Asian Studies 37(3): 397-413.
Elmhirst, Rebecca. 2007. Tigers and gangsters: Masculinities and feminised migration in Indonesia. Population, Space and Place 13(3):225-38.

Evans, Tony and Patti Wallace. 2008. A prison within a prison? The masculinity narratives of male prisoners. Men and Masculinities 10(4): 484-507.

Fabinyi, Michael. 2007. Illegal fishing and masculinity in the Philippines: A look at the Calamianes Islands in Palawan. Philippine Studies 55(4): 509-29.

2012. Fishing for fairness: Poverty, morality and marine resource regulation in the Philippines. Canberra: ANU E-Press.

Food and Agriculture Organization (FAO). 2013. The state of world fisheries and aquaculture. Rome: Food and Agriculture Organization.

Fuller, Norma. 2001. The social construction of gender identity among Peruvian men. Men and Masculinities 3(3): 316-31.

Gerrard, Siri. 2000. The gender dimensions of local festivals: The fishery crisis and women's and men's political actions in north Norwegian communities. Women's Studies International Forum 23(3): 299-309.

Guerrero, D. A. Vasquez. 2009. Hypermasculinity, intimate partner violence, sexual aggression, social support, and child maltreatment risk in urban, heterosexual fathers taking parenting classes. Child Welfare 88(4): 135-56.

Guieb, Eli R. 2009. Community, marine rights and tenure: A political ecology of marine conservation in two Bohol villages in central Philippines. PhD thesis, McGill University.

Hapke, Holly M. 2001. Gender, work, and household survival in South Indian fishing communities: A preliminary analysis. The Professional Geographer 53(3): 313-31.

Hapke, Holly and Devan Ayyankeril. 2004. Gender, the work-life course, and livelihood strategies in a South Indian fish market. Gender, Place and Culture 11(2): 229-56.

Hoang, Lan Anh and Brenda S.A. Yeoh. 2011. Breadwinning wives and "left-behind" husbands: Me and masculinities in the Vietnamese transnational family. Gender and Society 25(6): 717-39.

Jones, Peter N. 2005. Identity through fishing: A preliminary analysis of impacts to the Nez Perce as a result of the damming of the Clearwater and Snake Rivers. Cultural Dynamics 17(2): 155-92.

Kabeer, Naila. 2007. Marriage, motherhood and masculinity in the global economy: Reconfigurations of personal and economic life. IDS Working Paper, 290. Brighton: Institute of Development Studies, University of Sussex.

Kleiber, Danika, Leila M. Harris, and Amanda C. J. Vincent. 2014. Gender and small-scale fisheries: A case for counting women and beyond. Fish and Fisheries 15:1-16.

Kurien, John. 1998. Small-scale fisheries in the context of globalization. Thiruvananthapuram, Kerala: Center for Development Studies.

Liza. 2009. Interview by the author, San Juan, 24 Oct.

Mangahas, Maria. 2000. Managing luck and negotiating change: Ethnographies of fishing and sharing in the Philippines. PhD diss., University of Cambridge.

Mayo. 2008. Interview by the author, San Juan, 5 Nov.

McGoodwin, James R. 1991. Crisis in the world's fisheries: People, problems, and policies. Stanford Stanford University Press. 
McMillan, Anita Schrader and Moli Paul. 2011. 'It was good to learn how to show affection': Central American men who reject hypermasculinity. Community, Work and Family 14(3): 367-82.

Medard, Modesta and Douglas C. Wilson. 1996. Changing economic problems for women in the Nile perch fishing communities on Lake Victoria. Workshop in Political Theory and Policy Analysis. Bloomington, Indiana. Online, http://dlc.dlib.indiana.edu/dlc/bitstream/handle/10535/2290/ Changing_Economic_Problems_for_Women_in_the_Nile_Perch_Fishing_Communities_on Lake_Victoria.pdf?sequence=1, accessed 12 May 2014.

Menjivar, Cecilia. 2006. Global processes and local lives: Guatemalan women's work and gender relations at home and abroad. International Labor and Working-Class History 70:85-105.

Miriam. 2008. Interview by the author, San Juan, 28 Aug.

Mosher, David L. and Mark Sirkin. 1984. Measuring a macho personality constellation. Journal of Research in Personality 18:150-63.

Munk-Madsen, Eva. 2000. Wife the deckhand, husband the skipper: Authority and dignity among fishing couples. Women's Studies International Forum 23(3): 333-42.

Nadel-Klein, Jane. 2000. Granny baited the lines: Perpetual crisis and the changing role of women in Scottish fishing communities. Women's Studies International Forum 23(3): 363-72.

National Statistics Office (NSO). 2012. Census for fisheries. Quezon City: National Statistics Office, Republic of the Philippines.

Neis, Barbara, Siri Gerrard, and Nicole G. Power. 2013. Women and children first: The gendered and generational social-ecology of small-scale fisheries in Newfoundland and Labrador and northern Norway. Ecology and Society 18(4): 1-13.

Padilla, Jose E., Samuel Mamauag, Gilbert Braganza, Nilo Brucal, Dennis Yu, and Alvin Morales. 2003. Sustainability assessment of the live reef-fish for food industry in Palawan, Philippines. Quezon City: WWF-Philippines.

Parreñas, Rhacel. 2005. Children of global migration: Transnational families and gendered woes Stanford: Stanford University Press.

Perry, R. Ian and Rosemarry E. Ommer. 2003. Scale issues in marine ecosystems and human interaction. Fisheries Oceanography 12(4-5): 513-22.

Philippine Senate. 2013. Economic report. Pasay City: Senate Economic Planning Office.

Pingol, Alicia T. 2001. Remaking masculinities: Identity, power, and gender dynamics in families with migrant wives and househusbands. Quezon City: University of the Philippines Center for Women's Studies; Ford Foundation.

Pyle, J. L. and K. B. Ward. 2003. Recasting our understanding of gender and work during global restructuring. International Sociology 18(3): 461-89.

Raul. 2008. Interview by the author, San Juan, 12 Sept.

Rubinoff, Janet Ahner. 1999. Fishing for status: Impact of development on Goa's fisherwomen. Women's Studies International Forum 22(6): 631-44.

Sann, Alain Le. 1998. A livelihood from fishing: Globalization and sustainable fisheries policies. London: Intermediate Technology Publications.

Sara. 2009. Interview by the author, San Juan, 5 Jan.
Scott, James. 1985. Weapons of the weak: Everyday forms of peasant resistance. New Haven: Yale University Press.

Siar, S.V. 2003. Knowledge, gender, and resources in small-scale fishing: The case of Honda Bay, Palawan, Philippines. Environmental Management 31:569-80.

Siason, Ida M. 2001. Women in fisheries in the Philippines. In International symposium on women in Asian fisheries, ed. M. J. Williams, M. C. Nandeesha, V. P. Corral, E. Tech, and P.S. Choo, 69-77. Penang: ICLARM-World Fish Center.

Siason, Ida,E. Tech, K. I. Matics, P. S. Choo, M. Shariff, E. S. Heruwati, T. Susilowati, N. Miki, A. B. Shelly, K. G. Rajabharshi, R. Ranjit, P. G. N. Siriwardena, M.C. Nandeesha, and M. Sunderarajan, eds.2002. Women in fisheries in Asia. Penang: World Fish Center.

Silberschmidt, Margrethe. 2001. Disempowerment of men in rural and urban East Africa: Implications for male identity and sexual behavior. World Development 29(4): 657-71.

Silverio, Simeon G. 1982. The neighborhood sari-sari store. In The Philippine poor I: Two monographs, ed. Marie S. Fernandez, 57-135. Quezon City: Institute of Philippine Culture, Ateneo de Manila University.

Skaptadottir, Unnur Dis. 2000. Women coping with change in an Icelandic fishing community: A case study. Women's Studies International Forum 23(3): 311-21.

2004. Responses to global transformations: Gender and ethnicity in resource-based localities in Iceland. Polar Record 40(214): 261-67.

Sotto, F. B., C. Laron, M. Lim, and T. Heeger. 2001. Women's participation in sapyaw (haul seine) fishery on the eastern coast of Barangay Sillon, Bantayan Island, Cebu, Philippines. In International symposium on women in Asian fisheries, ed. M.J. Williams, M.C. Nandeesha, V. P. Corral, E. Tech, and P. S. Choo, 79-98. Penang: ICLARM-World Fish Center.

Taylor, William W., Michael G. Schechter, and Lois G. Wolfson, eds.2007. Globalization: Effects on fisheries resources. Cambridge: Cambridge University Press.

Turgo, Nelson. 2010. "Bugabugangdagat": The local life of a fishing community in the Philippines. $\mathrm{PhD}$ thesis, Cardiff University.

_ 2013. "Here, we don't just trade goods, we also 'sell' people's lives": Sari-sari stores as nodes of partial surveillance in a Philippine fishing community. Singapore Journal of Tropical Geography 34(3): 373-89.

2014. Redefining and experiencing masculinity in a Philippine fishing community. Philippine Sociological Review 62:7-38.

Vincent, Amanda C. J., Jessica J. Meeuwig, Marivic G. Pajaro, and Nelson C. Perante. 2007. Characterizing a small-scale, data-poor, artisanal fishery: Seahorses in the central Philippines. Fisheries Research 86:207-15.

Walter, Nicholas, Philippe Bourgois, and H. Margarita Loinaz. 2004. Masculinity and undocumented labor migration: Injured Latino day laborers in San Francisco. Social Science and Medicine 59:1159-68.

Weeratunge, Nireka, Katherine A. Snyder, and Choo Poh Sze. 2010. Gleaner, fisher, trader, processor: Understanding gendered employment in fisheries and aquaculture. Fish and Fisheries 11:405-20. 
Nelson Nava Turgo is research associate, Seafarers International Research Centre, Cardiff University, 52 Park Place, Cardiff CF10 3AT, Wales, United Kingdom. His research interests include qualitative research methods, fishing communities, the interface between literature and anthropology, literary theory and criticism, the human element of the maritime industry, autoethnography, and the geographies of globalization. His works have been published in Qualitative Research, Sociological Research Online, Sabangan, Singapore Journal of Tropical Geography, Social Science Diliman, Philippine Sociological Review, and Daluyan: Journal ng Wikang Filipino. He is also a published bilingual fictionist. <TurgoN@cardiff.ac.uk> 